\title{
Ureolytic Bacteria in Sheep Rumen
}

\author{
By L. van WYK* AND P. L. STEYN \\ Department of Microbiology-Plant Pathology, \\ University of Pretoria, 000 , Pretoria, South Africa
}

(Received 26 September 1974; revised 30 June 1975)

\begin{abstract}
SUMMARY
Estimates were made of the numbers of viable bacteria in the rumens of sheep receiving different rations. Representative colonies were isolated and tested for urease production. Some urease-positive isolates were characterized and identified. The ureolytic activities of the urease-producing isolates were determined and compared with the activity of rumen fluid. The rations fed to the sheep did not exert a significant influence on the relative numbers of the urease-producing organisms in the rumen. No obligately anaerobic ureolytic bacteria were found. All ureasepositive isolates were facultatively anaerobic, Gram-positive, catalase-positive cocci. Out of ten isolates, nine were identified as Staphylococcus saprophyticus and one as Micrococcus varians. The total urease activity of the different isolates based on the lowest numbers in which they were present in the rumen, compared favourably with the urease activity of rumen fluid. The facultatively anaerobic Grampositive cocci were probably responsible for a large proportion of the urease activity of the rumen fluid. Conditions prevailing in the rumen were found to be conducive to urease production by the isolates tested.
\end{abstract}

\section{INTRODUCTION}

The rumen is a strictly anaerobic environment (Hungate, 1966) possessing a high degree of urease activity at all times (Pearson \& Smith, 1943; Gibbons \& McCarthy, 1957; Jones, McLeod \& Blackwood, I964). Urease activity has so far been found to be almost completely absent from anaerobes (Cook, I972; Gibbons \& Doetsch, 1959), and a strictly anaerobic ureolytic bacterium isolated from the rumen was considered unimportant with regard to ureolysis in the rumen (Gibbons \& Doetsch, 1959). Most ureolytic bacteria isolated from the rumen were facultative anaerobes, but because of their relatively small numbers they were not considered to contribute significantly to the total ureolytic capacity of the rumen (Heald et al. 1953; Mann, Masson \& Oxford, I 954; Huhtanen \& Gall, 1955). Gram-positive facultatively anaerobic ureolytic cocci were isolated from the rumen by Heald et al. (I953) Mann et al. (1954) and Blackburn \& Hobson (1960); the role and importance of these organisms in urea hydrolysis has not been investigated fully. No plausible explanation has been advanced regarding the inability to isolate any organism or group of organisms that could account for the relatively high urease activity of rumen fluid. Accordingly Hungate (1966) suggested that a large number of urease-producing bacteria exist in the rumen, each contributing a small fraction of the total urease activity of the rumen. This was subsequently supported by the results of Cook (1972). In most studies washed cell suspensions were employed (Hungate, 1966) and when isolates were studied, few attempts were made at

\footnotetext{
* Present address: Research Institute for Tobacco, Private Bag, 0300 Rustenburg, Republic of South Africa.
} 
complete identification. A notable exception was the work of Cook (1972). Using direct plate counts and enrichment of serial dilutions he was able to isolate and identify ten ureolytic bacteria but found no obligate anaerobes.

The importance of ureolysis in supplying ammonia, together with the danger of urea poisoning, made it imperative that more information be obtained on the source of urease activity in the rumen. In the present work the number of urease-producing bacteria as a percentage of the total viable count was determined, and the influence of the ration of the ruminant on the relative numbers investigated. Some of the urease-positive bacteria were isolated in pure culture, described and identified. The urease activities of Gram- and ureasepositive, facultatively anaerobic cocci isolated from the rumen were determined and compared with the urease activities of corresponding rumen fluids. Factors that might affect urease activity of the isolates were investigated.

\section{METHODS}

Experimental animals. Four fully grown, rumen-fistulated Döhne Merino wethers were randomly selected. Each animal in turn received one of each of three rations. The daily basic ration consisted of $600 \mathrm{~g}$ frost-killed grass, $100 \mathrm{~g}$ mealie meal and $30 \mathrm{~g}$ mineral lick $\left(55 \%, \mathrm{w} / \mathrm{w}\right.$, commercial $\mathrm{NaCl}$ and $45 \%$ commercial $\left.\mathrm{K}_{2} \mathrm{HPO}_{4}\right)$. Rations $\mathrm{I}, 2$ and 3 consisted of the basic ration supplemented daily with $10 \mathrm{~g}$ urea, with $22 \mathrm{~g}$ fish meal plus $5 \mathrm{~g}$ urea, or with $44 \mathrm{~g}$ fish meal, respectively.

Anaerobic techniques and media. Strictly anaerobic techniques were employed during enumeration and isolation. The reducing solution of Bryant (1965) was used in all media, diluents and anaerobic liquids whenever it was necessary to reduce the redox potential. Resazurin was used at a final concentration of 0.000 \% \% (Bryant \& Burkey, I953; Hungate, 1960; Hungate, I966). The anaerobic liquids used for flushing hypodermic syringes consisted of previously-boiled, physiological salt solution $(0.85 \% \mathrm{NaCl}$ solution with $10 \%, \mathrm{v} / \mathrm{v}$, reducing solution and redox indicator), dispensed into containers previously gassed with an anaerobic gas mixture $\left(\mathrm{CO}_{2}-\mathrm{N}_{2}-\mathrm{H}_{2}, 50: 20: \mathrm{I}\right)$ and sterilized at I $2 \mathrm{I}{ }^{\circ} \mathrm{C}$ for $\mathrm{I} 5 \mathrm{~min}$.

Unless otherwise stated, all liquids and media were sterilized similarly. The anaerobic diluent of Toerien (I969) was used, with indigodisulphonate substituted by resazurin. Rumen fluid from at least four sheep receiving the basic ration was mixed, filtered through doubly-layered cheese cloth, centrifuged for $10 \mathrm{~min}$ at $10000 \mathrm{~g}$, the supernatant decanted into $120 \mathrm{ml} \mathrm{McCartney} \mathrm{bottles} \mathrm{and} \mathrm{gassed} \mathrm{for} 5 \mathrm{~min}$ with the anaerobic gas mixture. The bottles were capped with tightly-fitting rubber stoppers, sterilized, and stored at $4{ }^{\circ} \mathrm{C}$ until used. The anaerobic medium of Bryant \& Burkey (1953) was used with the reducing solution of Bryant (1965) instead of cysteine hydrochloride. The medium was prepared, and $4.5 \mathrm{ml}$ quantities dispensed into Astell roll tubes, under a constant positive pressure $\left(90 \% \mathrm{CO}_{2}\right.$, I0 $\% \mathrm{H}_{2}$ ). Tightly-fitting rubber stoppers were used instead of conventional Astell rubber stoppers. All media and medium containers were gassed with the anaerobic gas mixture before the addition of the reducing solution. Gas mixtures were obtained by mixing commercial gasses with the aid of flow meters and the residual oxygen was removed by passage through a Deoxo catalytic purifier (Engelhard Industries, London).

Rumen sampling. Animals were adapted to each ration for 3 weeks before samples were taken. Samples were taken $4 \mathrm{~h}$ after feeding and placed in $300 \mathrm{ml}$ containers, which were filled to the brim and rubber stoppered to exclude air as far as possible.

Total viable counts. Counts of the rumen contents were made according to the method of Kistner (1960) within 80 min of sampling. Serial dilutions were made with sterile hypodermic 
syringes. Portions ( $\mathrm{I} \mathrm{ml}$ ) of suitable dilutions were plated in triplicate on anaerobic agar in Astell tubes and incubated for $96 \mathrm{~h}$ at $38{ }^{\circ} \mathrm{C}$.

Isolation and culturing of bacteria under anaerobic conditions. All isolations were of representative colonies from $10^{7}$-dilution plates, because only bacteria present in the rumen in numbers exceeding $10^{7} / \mathrm{ml}$ are of any significance (Bryant \& Burkey, I953; Bryant, I959; Gibbons \& Doetsch, I959; Hungate, Bryant \& Mah, I964; Hungate, I966). These tubes contained from 20 to 200 colonies and were used in viable counts. Isolations were made from the tubes whose colony numbers were closest to the average for the three tubes of the dilution. Tests for purity of cultures were based on colony form, size and colour, as well as on size and Gram reaction of the bacteria. Pure cultures were maintained anaerobically on slants until urease activity and the influence of oxygen on the growth and survival of the organisms could be studied. Since all urease-positive isolates were found to be facultatively anaerobic, strictly anaerobic culturing was discontinued. The urease activities of all the isolates were qualitatively determined according to the method of Gibbons \& Doetsch (I959).

Description and identification of urease-producing isolates. Unless otherwise stated, $24 \mathrm{~h}$ cultures grown on nutrient agar at $37^{\circ} \mathrm{C}$ were used in all diagnostic tests. Cellulolytic and proteolytic activity were determined under anaerobic and aerobic conditions. Cellulolytic activity was determined according to the method of Mann (1968). Casein (Difco) was used as a source of protein in proteolysis tests. All other diagnostic tests were carried out according to the standard methods described by Cruickshank (1965).

Quantitative determination of urease activity. Urease-positive isolates were grown aerobically for $24 \mathrm{~h}$ at $37^{\circ} \mathrm{C}$ on nutrient agar, collected from the surface with sterile physiological saline solution and washed thrice by centrifuging and resuspending the pellet in saline. The pellet was then suspended in I $\%(\mathrm{w} / \mathrm{v}) \mathrm{NaHCO}_{3}$ and the cell density was turbidimetrically standardized to contain approximately $10^{7}$ bacteria $/ \mathrm{ml}$. Urease activity was determined quantitatively by the method of Huhtanen \& Gall (I955), modified in that $\mathrm{I}^{\circ} \mathrm{O}$ instead of $0.9 \% \mathrm{NaHCO}_{3}$ solution, I ml rumen fluid instead of $3 \mathrm{ml}$, and $0.5 \mathrm{ml}$ instead of $0.1 \mathrm{ml}$ of $0.5 \mathrm{M}$-urea solution were used in the manometric flasks. A Braun model V Warburg apparatus with one-armed flasks of approximately $14 \mathrm{ml}$ capacity was used. The main compartment contained $2 \mathrm{ml} \mathrm{NaHCO}$ solution and $\mathrm{I} \mathrm{ml}$ cell suspension or rumen fluid, with the urea solution in the side arm. For each experimental flask a control flask $(0.85 \% \mathrm{NaCl}$ in place of urea) was used to correct for endogenous respiration.

Urease activity of the rumen fluid was determined similarly, with rumen fluid replacing the cell suspension. Before experimentation the rumen fluid was gassed for 5 min with $\mathrm{CO}_{2}$ and the $\mathrm{pH}$ adjusted to 6.8 with $6.9 \%(\mathrm{w} / \mathrm{v}) \mathrm{NaHCO}_{3}$ solution when necessary.

Inducibility of urease. The isolates were subcultured at least four times on nutrient agar without any added urea. The bacteria from a $24 \mathrm{~h}$ nutrient agar slant were harvested, washed twice in sterile saline solution and disrupted with an MSE ultrasonic disintegrator at $4{ }^{\circ} \mathrm{C}$. The resultant liquid was centrifuged for $10 \mathrm{~min}$ at $10000 \mathrm{~g}$ and $4{ }^{\circ} \mathrm{C}$, and the supernatant removed. To test the supernatant qualitatively for urease activity, three drops of the crude enzyme preparation were mixed with three drops of a $0.3 \%$ urea solution on a porcelain plate; ten equivalent mixtures were prepared and three drops of Nessler's reagent added one at a time at I min intervals. The evolution of ammonia was taken as proof of urease production. 
Table I. Total viable anaerobic bacterial counts, and urease activity of bacterial isolates from rumen fluid of four sheep receiving three different rations

\begin{tabular}{|c|c|c|c|c|c|c|c|}
\hline \multirow[b]{2}{*}{ Sheep } & \multirow[b]{2}{*}{ Ration } & \multicolumn{3}{|c|}{ Total counts and calculated data } & \multicolumn{3}{|c|}{$\begin{array}{c}\begin{array}{c}\text { Percentage of isolates with } \\
\text { urease activity* }\end{array}\end{array}$} \\
\hline & & $\begin{array}{l}90 \% \text { confidence } \\
\text { intervals } \\
\left(10^{7} / \mathrm{ml}\right)\end{array}$ & $\begin{array}{l}\text { Standard } \\
\text { deviation }\end{array}$ & $\begin{array}{c}\text { Coefficient } \\
\text { of variation } \\
(\%)\end{array}$ & $\begin{array}{l}\text { Strongly } \\
\text { positive }\end{array}$ & $\begin{array}{l}\text { Fairly } \\
\text { positive }\end{array}$ & $\begin{array}{l}\text { Weakly } \\
\text { positive }\end{array}$ \\
\hline I & $\begin{array}{l}I \\
2 \\
3\end{array}$ & $\begin{array}{l}57 \pm 4 \\
55 \pm 15 \\
92 \pm 18\end{array}$ & $\begin{array}{r}2 \\
9 \\
10\end{array}$ & $\begin{array}{r}4 \\
16 \\
11\end{array}$ & $\begin{array}{l}8 \\
9 \\
0\end{array}$ & $\begin{array}{r}17 \\
9 \\
17\end{array}$ & $\begin{array}{r}0 \\
9 \\
17\end{array}$ \\
\hline 2 & $\begin{array}{l}\text { I } \\
2 \\
3\end{array}$ & $\begin{array}{l}82 \pm 19 \\
43 \pm 5 \\
69 \pm 14\end{array}$ & $\begin{array}{r}12 \\
3 \\
8\end{array}$ & $\begin{array}{r}14 \\
7 \\
12\end{array}$ & $\begin{array}{r}0 \\
\text { II } \\
0\end{array}$ & $\begin{array}{l}0 \\
0 \\
0\end{array}$ & $\begin{array}{r}33 \\
0 \\
0\end{array}$ \\
\hline 3 & $\begin{array}{l}I \\
2 \\
3\end{array}$ & $\begin{array}{c}73 \pm 26 \\
69 \pm 9 \\
102 \pm 13\end{array}$ & $\begin{array}{r}15 \\
6 \\
8\end{array}$ & $\begin{array}{r}21 \\
8 \\
8\end{array}$ & $\begin{array}{r}8 \\
14 \\
0\end{array}$ & $\begin{array}{l}0 \\
0 \\
0\end{array}$ & $\begin{array}{l}8 \\
0 \\
0\end{array}$ \\
\hline 4 & $\begin{array}{l}1 \\
2 \\
3\end{array}$ & $\begin{array}{c}125 \pm 39 \\
67 \pm 13 \\
55 \pm 8\end{array}$ & $\begin{array}{r}23 \\
8 \\
5\end{array}$ & $\begin{array}{r}\text { I } 8 \\
\text { I I } \\
9\end{array}$ & $\begin{array}{l}27 \\
18 \\
21\end{array}$ & $\begin{array}{l}0 \\
9 \\
0\end{array}$ & $\begin{array}{l}0 \\
9 \\
0\end{array}$ \\
\hline
\end{tabular}

* Percentages calculated from the total number of isolates per sheep ration.

\section{RESULTS AND DISCUSSION \\ Bacterial counts}

A statistical analysis (Table I) of the total counts of anaerobic bacteria in the rumen fluid of sheep on different rations shows that differences occurred among counts obtained from rumen fluid samples from the same sheep on different rations, as well as between counts of three different sheep receiving the same ration. Total viable counts on rumen samples obtained by different workers differ considerably, for example from $18 \times 10^{9}$ to $44 \times 10^{9}$ (Williams \& Moir, I95I) and I $3 \times 10^{9}$ (Bryant \& Burkey, 1953). Counts made before feeding were usually found to be lower than those made after feeding (Hungate, 1966) and this may explain the relatively low counts we obtained, which were made on samples drawn $4 \mathrm{~h}$ after feeding. However, results from this study confirmed those obtained by Bryant \& Burkey (1953). Although the coefficients of variation vary considerably, the results compare favourably with those of Cook \& Steel (1959). Kistner (1960) obtained much lower coefficients of variation but in his case counts were made of a single physiological group (cellulolytic bacteria).

The percentages of strongly, moderately and weakly ureolytic isolates obtained from the same rumen fluid of four different sheep receiving three different rations are also shown in Table $\mathrm{I}$. The urea content of the ration did not exert a significant influence on the percentage of urease-positive isolates. Furthermore, there was no correlation between the distribution of the percentages of strongly, moderately or weakly ureolytic isolates and the urea content of the rations. This was in agreement with the results of Pearson \& Smith (1943).

\section{Description and identification of ureolytic isolates}

No obligately anaerobic ureolytic isolates were found. All isolates were facultatively anaerobic and their ureolytic properties were virtually unaffected by oxygen. However, upon repeated aerobic subculturing as many as $50 \%$ of the isolates became urease-negative. The ten isolates retaining their ureolytic properties were labelled A33i, A33ii, A48, BI $7 \mathrm{ii}$, B24, B27i, C23, D4I, D45ii and D49. 
Table 2. Characteristics of ureolytic isolates from the sheep rumen

No isolates: (i) produced acid from arabinose, rhamnose, xylose, cellobiose, raffinose, inulin, dulcitol, inositol, mannitol, sorbitol or salicin; (ii) utilized citrate or malonate; (iii) produced cellulase (either aerobically or anaerobically), coagulase, $\mathbf{H}_{2} \mathrm{~S}$ or indole; (iv) hydrolysed starch.

\begin{tabular}{|c|c|c|c|c|c|c|c|}
\hline & & & & on of $i$ & & & \\
\hline & $\mathbf{B} 27 \mathrm{i}$ & & & & & & \\
\hline Property & $\begin{array}{l}\text { A33ii } \\
\text { D4I }\end{array}$ & A48 & $\begin{array}{l}\text { A33i } \\
\text { D49 }\end{array}$ & $\mathrm{C} 23$ & B24 & BI $7 \mathrm{ii}$ & D45ii \\
\hline Gram stain & + & + & + & + & + & + & + \\
\hline Acid-fast stain & - & - & - & - & - & - & - \\
\hline Spore stain & - & - & - & - & - & - & - \\
\hline Acid produced from & & & & & & & \\
\hline Fructose & + & + & + & - & + & - & + \\
\hline Galactose & + & + & + & + & + & - & - \\
\hline Glucose & + & + & + & + & + & - & + \\
\hline Mannose & + & + & + & + & + & - & - \\
\hline Lactose & + & + & + & - & + & - & - \\
\hline Maltose & + & + & + & + & + & + & + \\
\hline Sucrose & + & + & + & + & + & \pm & + \\
\hline Trehalose & - & - & - & - & - & + & + \\
\hline Melezitose & \pm & \pm & \pm & \pm & \pm & \pm & \pm \\
\hline Glycerol & $\overline{+}$ & + & + & $\bar{t}$ & $\bar{t}$ & $\overline{+}$ & $\bar{t}$ \\
\hline $\begin{array}{l}\text { Oxidation/fermenta- } \\
\text { tion of }\end{array}$ & & & & & & & \\
\hline Glucose & f & $f$ & $\mathrm{f}$ & $f$ & f & o & f \\
\hline Lactose & f & f & $\mathrm{f}$ & - & f & - & - \\
\hline Maltose & $\mathbf{f}$ & $\mathrm{f}$ & $\mathrm{f}$ & $\mathrm{f}$ & f & o & $\mathbf{o}$ \\
\hline Catalase & + & + & + & + & + & + & + \\
\hline Gelatinase & + & + & + & + & + & - & - \\
\hline Lipase & + & + & + & + & + & + & + \\
\hline Phosphatase & + & + & + & + & + & - & - \\
\hline Urease & & & & & & & \\
\hline Aerobic & + & + & + & + & + & + & + \\
\hline Anaerobic & + & + & + & + & + & + & + \\
\hline $\mathrm{NH}_{4}{ }^{+}$assimilation & $?$ & $?$ & $?$ & $?$ & $?$ & $?$ & $?$ \\
\hline $\mathrm{NO}_{3}$ reduction & + & - & + & + & + & + & + \\
\hline Acetion production & + & + & + & - & - & - & - \\
\hline Methyle blue reduction & + & + & + & + & + & + & + \\
\hline Methyl red test & + & + & + & + & + & + & + \\
\hline Litmus milk & ac & $\mathrm{a}$ & $\mathrm{k}$ & $\mathrm{kc}$ & ac & $\mathrm{k}$ & $\mathrm{k}$ \\
\hline Casein hydrolysis & + & + & + & + & + & - & - \\
\hline Deamination & & & & & & & \\
\hline Aerobic & + & + & + & + & + & - & \pm \\
\hline Anaerobic & + & + & + & + & + & - & \pm \\
\hline Final $\mathrm{pH}$ of glucose & $4 \cdot 8$ & $4 \cdot 6$ & $4 \cdot 3$ & 49 & $4 \cdot 9$ & $4 \cdot 5$ & $4 \cdot 5$ \\
\hline
\end{tabular}

+ , Positive reaction; - , negative reaction; \pm , weak positive reaction. $f$, Fermentation; o, oxidation; ?, inconclusive results. a, Acid reaction; $\mathrm{k}$, alkaline reaction; ac, acid coagulation; kc, alkaline coagulation.

Colonies of isolates BI 7ii and D45ii on nutrient agar were $\mathrm{I} \mathrm{mm}$ in diameter, round to rounded, and off-white. On blood agar the colonies were larger $(2 \mathrm{~mm})$ and grey. The other isolates formed similar mucoid colonies on nutrient agar, whereas colonies on blood agar were blue-grey and $\mathrm{I} \mathrm{mm}$ in diameter. All isolates consisted of non-motile, Gram-positive cocci. Cells of isolates A33i, A33ii, A48, B24, D4I and D49 were $\mathrm{I} \cdot 5$ to $\mathrm{I} \cdot 7 \mu \mathrm{m}$ in diameter, and appeared as monococci, diplococci and staphylococci in the same culture. Isolates D45ii and, especially, BI 7 ii possessed a strong tendency to form tetrads, although monococci, diplococci and even short chains were observed in the same culture. In isolate B 7 ii the cells 
Table 3. Urease activity of rumen fluid and bacterial isolates

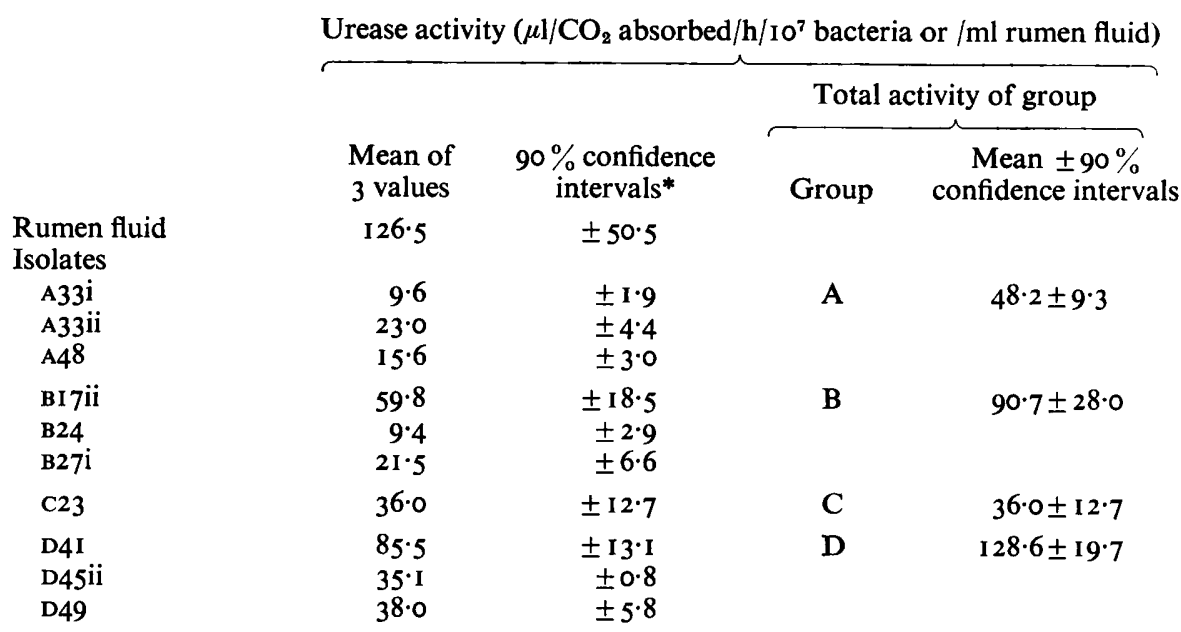

* Confidence intervals for bacterial isolates were calculated from experimental data and standard deviations obtained for viable counts of rumen fluid (see Table $\mathrm{I}$ ).

of the tetrad were of the same size, whereas in isolate D45ii two of the four cells were smaller. Cell form and the tendency to form aggregates did not differ in liquid or agar culture. Except for isolate Brjii, which produced a yellow pigment on potato agar slants, no pigment was formed by any of the isolates. All isolates produced a tenacious sediment in liquid medium and carbon dioxide was not essential for growth. The optimum, maximum and minimum growth temperatures of all isolates were 37,45 and $5{ }^{\circ} \mathrm{C}$, respectively. All isolates grew in the presence of $5 \% \mathrm{NaCl}$. The biochemical and other properties of the isolates are presented in Table 2. Bergey's Manual of Determinative Bacteriology (1974) was used for the identification of the isolates. None of the isolates conformed entirely to any one of the species listed. Nine out of ten isolates were tentatively identified as Staphylococcus saprophyticus (Fairbrother) emend. mut. char. (Shaw, Stitt \& Cowan, I95I) and one (BI7ii) as Micrococcus varians Migula. This corroborated to a large extent the results of Cook (1972), who isolated seven strains of Staphylococcus from the rumen, and to a lesser extent the results of Abou Akkada \& Blackburn (I963), who isolated two aerobic ureolytic cocci.

\section{Urease activity of isolates and rumen fluid}

The total urease activity of the isolates from the same rumen sample was considered to give a good indication of the relative importance of the contributions of these organisms to the urease activity in vitro of rumen fluid (Table 3). It was apparent that the urease activities of group D and even group B isolates fell well within the possible limits of the urease activity of rumen fluid. Therefore, the urease activity of the facultatively anaerobic, Gram-positive cocci could largely account for the urease activity of rumen fluid. These results differ considerably from those of Heald et al. (1953), Mann et al. (1954), Huhtanen \& Gall (I955) and Gibbons \& McCarthy (1957), who expressed the opinion that on the basis of the relatively small numbers of their populations, the facultative anaerobes could play only a minor role in the urease activity of the rumen, but agree with the results of Cook (I972), who isolated a Streptococcus species which under anaerobic conditions possessed urease activity sufficient to account for most of the ureolytic activity of the sheep rumen. Furthermore 
Table 4. Influence of various factors on urease production by two bacterial isolates from rumen

Only one strongly urease-positive isolate of each species was tested. With the exception of casein hydrolysate effects of factors were investigated in nutrient broth (Kyokuto, Japan) containing $0.5 \%$ $\mathrm{NaCl}$ and no added urea, supplemented with $\mathrm{I} \%(\mathrm{w} / \mathrm{v})$ glucose. For $100 \%$ rumen fluid the broth was reconstituted with filtered rumen fluid instead of water. Urea was added as concentrated filtersterilized solutions. Casein hydrolysis was tested in a $\mathrm{I} \%(\mathrm{w} / \mathrm{v})$ solution of glucose. Where applicable the isolates were grown anaerobically under $\mathrm{CO}_{2}$ in broth supplemented (per $100 \mathrm{ml}$ ) with I ml reducing solution (Bryant, 1965 ) and $1 \mathrm{ml}$ of a $0.01 \%$ resazurin solution. All media were inoculated with a small inoculum from a $24 \mathrm{~h}$ nutrient-agar slant culture and incubated at $37^{\circ} \mathrm{C}$ for $48 \mathrm{~h}$. Suspensions of washed cells were standardized turbidimetrically for each factor separately, permitting comparison within a factor but not between factors.

\begin{tabular}{|c|c|c|c|}
\hline \multirow[b]{2}{*}{ Factor } & \multirow[b]{2}{*}{$\begin{array}{c}\text { Concentration } \\
(\%)\end{array}$} & \multicolumn{2}{|c|}{$\begin{array}{l}\text { Urease activity ( } \mu \mathrm{l} \mathrm{CO}_{2} \text { absorbed } / \mathrm{h} / \mathrm{ml} \\
\text { cell suspension) }\end{array}$} \\
\hline & & $\begin{array}{c}\text { Micrococcus } \\
\text { varians } \\
\text { (BI 7ii) }\end{array}$ & $\begin{array}{l}\text { Staphylococcus } \\
\text { saprophyticus } \\
\text { (D41) }\end{array}$ \\
\hline $\mathrm{NaCl}$ & $\begin{array}{r}0.5 \\
5.0 \\
15.0 \\
25.0\end{array}$ & $\begin{array}{c}67 \\
21 \\
8 \\
-*\end{array}$ & $\begin{array}{c}42 \\
44 \\
6 \\
-*\end{array}$ \\
\hline Urea & $\begin{array}{l}0 \\
0 \cdot 2 \\
2 \cdot 0\end{array}$ & $\begin{array}{r}87 \\
\text { I06 } \\
93\end{array}$ & $\begin{array}{l}349 \\
297 \\
225\end{array}$ \\
\hline$\left(\mathrm{NH}_{4}\right)_{2} \mathrm{SO}_{4}$ & $\begin{array}{l}0 \\
0.1 \\
0.25 \\
0.5 \\
1.0 \\
2.5\end{array}$ & $\begin{array}{l}54 \\
17 \\
13 \\
32 \\
14 \\
18\end{array}$ & $\begin{array}{r}203 \\
109 \\
184 \\
228 \\
\text { I } 38 \\
91\end{array}$ \\
\hline Rumen fluid & $\begin{array}{c}0 \\
40 \cdot 0 \\
100 \cdot 0\end{array}$ & $\begin{array}{l}48 \\
75 \\
66\end{array}$ & $\begin{array}{l}23 \\
55 \\
23\end{array}$ \\
\hline Casein & $\begin{array}{l}0 \\
0 \cdot I\end{array}$ & $-{ }^{*}$ & $\frac{-*}{6}$ \\
\hline Hydrolysate & $\begin{array}{r}0.5 \\
1.0 \\
5.0 \\
10.0 \\
15.0\end{array}$ & $\begin{array}{r}9 \\
19 \\
133 \\
124 \\
183\end{array}$ & $\begin{array}{l}152 \\
121 \\
228 \\
258 \\
286\end{array}$ \\
\hline Aerobiosis & 一 & 15 & 28 \\
\hline Anaerobiosis & - & 69 & 45 \\
\hline
\end{tabular}

* No growth occurred.

isolates of the same species differed considerably in their urease activity (e.g. isolates D4I and B24). Therefore, when assessing the possible role of certain bacterial populations in ureolysis, the total activity of several isolates should be calculated from their specific activities and lowest numbers in the rumen.

\section{Influence of different factors on urease production}

Staphylococcus saprophyticus (D4I) was not affected by increased salt concentrations to. the degree shown by $M$. varians (BI 7ii) (Table 4).

We did not find a consistent increase in urease production when urea was omitted from the medium, which contrasts with the results of Gibbons \& Doetsch (1959). 
Although $\left(\mathrm{NH}_{4}\right)_{2} \mathrm{SO}_{4}$ suppressed urease production, the effect was less severe than observed in the experiments of Gibbons \& Doetsch (1959), who found that $0.5 \%\left(\mathrm{NH}_{4}\right)_{2} \mathrm{SO}_{4}$ completely suppressed urease production.

Rumen fluid stimulated urease production, possibly because of unknown growth factors.

Anaerobic conditions stimulated urease production, which is in agreement with the results of Cook (1972) for a Streptococcus species.

Conditions prevailing in the rumen should therefore stimulate bacterial urease production so that in vivo urease activity will be higher than in vitro.

\section{Inducibility of urease}

All cultures were urease-positive after growth on nutrient agar, indicating constitutive production of the enzyme.

\section{REFERENCES}

Abou AkKada, A. R. \& BlackbuRn, T. H. (1963). Some observations on the nitrogen metabolism of rumen proteolytic bacteria. Journal of General Microbiology 3I, 46I-469.

Bergey's Manual of Determinative Bacteriology (1974), 8th edn. Edited by R. E. Buchanan and N. E. Gibbons. Baltimore: The Williams \& Wilkins Co.

Blackburn, T. H. \& Hobson, P. N. (1960). Proteolysis in the sheep rumen by whole and fractioned rumen contents. Journal of General Microbiology 22, 272-28I.

BRYANT, M. P. (1959). Bacterial species of the rumen. Bacteriological Reviews 23, 125-153.

BRYANT, M. P. (I965). Rumen methanogenic bacteria. In Physiology of Digestion in the Ruminant. Edited by R. W. Dougherty and others. London: Butterworths.

BRYANT, M. P. \& BURKEY, L. A. (I953). Cultural methods and some characteristics of some of the more numerous groups of bacteria in the bovine rumen. Journal of Dairy Science 36, 205-217.

CooK, A. R. (1972). Ureolysis in the ovine rumen. Biochemical Journal 127, 66.

COOK, A. M. \& STEEL, R. G. (1959). A method for the preparation of bacterial dilutions. Laboratory Practice 8, 359 .

CRUICKSHANK, R. (1965). Medical Microbiology, i Ith edn. London: E. \& S. Livingstone.

GibBons, R. J. \& DOETSCH, R. N. (1959). Physiological study of an obligately anaerobic ureolytic bacterium. Journal of Bacteriology 77, 417-428.

GrbBons, R. J. \& MCCARTHY, R. D. (I957). Obligately anaerobic urea hydrolysing bacteria in the bovine rumen. In Maryland Agricultural Experimental Station Miscellaneous Publication 291, 12-I6.

Heald, P. J., Krogh, N., Mann, S. O., Appleby, J. C., Masson, F. M. \& Oxford, A. E. (1953). A method for direct viable counts of the facultatively anaerobic microflora in the rumen of a sheep on hay diet. Journal of General Microbiology 9, 207-21 5.

HuHTANEN, C. N. \& GALL, L. S. (I955). Manometric estimation of rumen urease. Journal of Bacteriology 69, I02-103.

HungATE, R. E. (1960). Microbial ecology of the rumen. Bacteriological Reviews 24, 353-364.

HuNGATE, R. E. (1966). The Rumen and Its Microbes. New York: Academic Press.

Hungate, R. E., Bryant, M. P. \& MaH, R. A. (1964). The rumen bacteria and protozoa. Annual Review of Microbiology I8, I3 I-I 66.

Jones, G. A., MacLeod, R. A. \& Blackwood, A. C. (I964). Ureolytic rumen bacteria. I. Characteristics of the microflora from a urea-fed sheep. Canadian Journal of Microbiology 10, 371-378.

KISTNER, A. (1960). An improved method for viable counts of bacteria of the ovine rumen which ferment carbohydrates. Journal of General Microbiology 23, 565-567.

MANN, S. O. (1968). An improved method for determining cellulolytic activity in anaerobic bacteria. Journal of Applied Bacteriology 31, 24I-244.

MANN, S. O., MASSON, F. M. \& OxFORD, A. E. (1954). Facultative anaerobic bacteria from the sheep rumen. Journal of General Microbiology ro, I42-149.

Pearson, R. M. \& Smith, J. A. B. (I943). The utilization of urea in the bovine rumen. II. The conversion of urea to ammonia. Biochemical Journal 37, I48-1 53.

Shaw, C., StitT, J. M. \& Cowan, S. T. (I95I). Staphylococci and their classification. Journal of General Microbiology 5 , 1010-1023.

ToErIen, D. F. (1969). Population description of the non-methanogenic phase of anaerobic digestion. D.Sc. thesis, University of Pretoria.

WiLliams, V. J. \& MoIR, R. J. (I95I). Ruminal flora studies in the sheep. II. The effect of the level of nitrogen intake upon the total number of free micro-organisms in the rumen. Australian Journal of Scientific Research 3, 38I-392. 